\title{
Kolelitiazisli Hastalarda Serum Lipit Profili
}

\author{
Rakesh POKHREL ${ }^{1}$, Parshal BHANDARI ${ }^{2}$, Binod ARYAL ${ }^{1}$
}

\begin{abstract}
$\ddot{\mathbf{O z}}$
$\mathrm{Bu}$ araştırma, kolelitiazis tanısı alan hastalarda lipid profili durumunu ilişkilendirmeyi amaçlamaktadır. Biyokimya Anabilim Dalı'nda tamamlanmış bir gözlemsel vaka kontrol çalışmasıdır. Toplam 100 denek seçildi ve iki gruba ayrıldı. Gruplar kolelitiazisli 50 hasta (grup A) ve 50 sağlıklı kontrol gruptan (grup B) oluşmaktaydı. Araştırma, 1 Mart 2016 ile 31 Ekim 2016 tarihleri arasında sekiz ay içinde tamamlandı. Kolelitiazisin doğrulanması Radyolog tarafindan ultrason çalışmaları ile gerçekleşmiştir. Grup A ve grup B seçimi radyolojik bulgulara dayanarak yapıldı. Tüm olguların lipit profilleri için açlık kan örnekleri topland 1 ve lipit profil testleri biyokimya laboratuarında yapıldı. Olguların farklı parametrelerinin belgelenmesi için öz-tasarımlı form kullanıldı. Trigliserit (TG) ve Yüksek Yoğunluklu Lipidler (HDL) istatistiksel olarak anlamlı bulundu. (Sırasıyla, $\mathrm{p}=0.005$ ve $\mathrm{p}=$ $0.001)$. Safra taşı olan hastalarda ortalama TG seviyesi $(1.9 \mathrm{mmol} / \mathrm{l})$ normal olgulardan $(1.45$ $\mathrm{mmol} / \mathrm{1})$ daha yüksek bulundu. Hastalarda ortalama HDL düzeyi $(0.95 \mathrm{mmol} / 1)$ normal olgulardan $(1.05 \mathrm{mmol} / \mathrm{l})$ düşüktü. Sonuç olarak kolelitiazisli hastalarda lipit profillerinin değiştiğini düşünmekteyiz.
\end{abstract}

Anahtar Kelimeler: Kolelitiazis, total kolesterol, trigliserit, yüksek yoğunluklu lipid, düşük yoğunluklu lipid

\section{Serum Lipid Profile in Patients with Cholelithiasis}

Rakesh POKHREL ${ }^{1}$, Parshal BHANDARI ${ }^{2}$, Binod ARYAL ${ }^{1}$
Gönderi Tarihi: 05.10.2018

Kabul Tarihi: 11.10 .2018

Online Yayın Tarihi: 30.06.2019

DOI: $10.26453 /$ otjhs. 467734

Sorumlu Yazar

Binod ARYAL

Darbar Devisthan-3,Charpala, Gulmi,

Nepal

Email: aryalbinod17@gmail.com

Phone no: (+977)9849841935

\begin{abstract}
This research aims to correlate status of lipid profile in the patients diagnosed with cholelithiasis. It is an observational case control study, completed in the Biochemistry department of Tribhuvan University and Teaching Hospital (TUTH). Total 100 subjects were selected and divided in two groups. The groups consisted of 50 patients with cholelithiasis (group A) and 50 healthy control groups (group B). The research was completed within a time of eight months commencing from $1^{\text {st }}$ March 2016 to $31^{\text {st }}$ October 2016. Confirmation of cholelithiasis was performed with ultrasound studies by radiologist. Selection of group A and group B were done on basis of radiological findings. Fasting blood samples for lipid profiles of all subjects were collected and lipid profile tests done in bio-chemistry lab. Self-designed form was used for documentation of different parameters of subjects. Triglyceride (TG) and High-Density Lipids (HDL) were found to be statically significant $(\mathrm{p}=0.005$ and $\mathrm{p}=0.001$, respectively). Mean TG level in patients with cholelithiasis $(1.9 \mathrm{mmol} / \mathrm{l})$ was found higher than in normal cases $(1.45 \mathrm{mmol} / \mathrm{l})$. Mean HDL level in patients $(0.95 \mathrm{mmol} / \mathrm{l})$ was lower than normal cases with $(1.05 \mathrm{mmol} / \mathrm{l})$. In conclusion, we think that lipid profiles altered in patients with cholelithiasis.
\end{abstract}

Keywords: Cholelithiasis, total cholesterol, triglyceride, high density lipid, low density lipid

${ }^{1}$ Tribhuvan University Teaching Hospital(TUTH), Kathmandu, Nepal

${ }^{2}$ Medical Officer, Nepal Medical College and Teaching Hopital, Kathmandu, Nepal
Article Info

Received: 05.10.2018

Accepted: 11.10.2018

Online Published: 30.06 .2019

DOI: 10.26453/otjhs.467734

Corresponding Author

Binod ARYAL

Darbar Devisthan-3,Charpala, Gulmi,

Nepal

Email: aryalbinod17@gmail.com

Phone no: (+977)9849841935 


\section{INTRODUCTION}

Cholelithiasis is one of the most encountered pathology of gastrointestinal system. Gall stones are mainly of three types: 1) cholesterol stones$80 \%$ 2) pigment stones and 3) mixed stones. ${ }^{1}$ Most of the patients with this disease are asymptomatic. ${ }^{2}$ These risk factors include increasing age, sex, dietary, high calorie intake, low fiber intake, high refined carbohydrates, hypertriglyceridaemia, physical inactivity, pregnancy, parity, overweight and obesity. ${ }^{3}$ Alternation of lipid metabolism is highly accepted in the pathogenesis of cholesterol stones. ${ }^{2}$ Due to altered lipid metabolism there is relative increase of cholesterol level compared to other lipids secreted by liver into the bile which is considered as main trigger for entire pathophysiological process in formation of cholesterol gall stone..$^{2-4}$

The principle objective of underhand research paper is targeted on the relation of serum lipid profile and gall stone disease.

\section{MATERIAL AND METHODS}

An observational case control study was performed in the Department of Biochemistry on coordination with Department of Surgery in TUTH. The research was completed within a time of eight months commencing from $1^{\text {st }}$ March 2016 to $31^{\text {st }}$ October 2016. Approval from ethical committee of institute and hand-written consent from selected candidates were taken. The selected total of 100 candidates were placed on two groups. In group A there were 50 cases with cholelithiasis and group B consisted of 50 cases who were normal. A self-designed form was used for collection of information's which included Name, Age, Sex, Ultrasound findings, Lipid profile data's, History of drugs and many more. Comparison between lipid profiles of group A and group B done. Both male and female of Age $>18$ years were included. Patients who are on lipid lowering drugs, oral contraceptives pills (OCP'S), steroids were excluded.

Ultrasound study was carried out with radiologist for confirmation of gall stone and venous blood sample were collected from all candidates after an overnight fasting for lipid profiles. Total cholesterol, Triglyceride (TG), High Density Lipid (HDL), Low Density Lipid (LDL) were evaluated in lipid profile using enzymatic calorimetric test. Data's were evaluated using SPSS V. 20 for calculation of mean and standard deviation (SD). Students T-test was used to compare means between case and control groups. $\mathrm{p}<0.05$ was considered statically significant.

\section{RESULTS}

Group A consist of 50 cases, $33(66 \%)$ were female and 17 (34\%) were male. In group B 26 (52\%) were female and $24(48 \%)$ were male (Table 1, Fig 1a,1b). Female population were 
found to be more affected with gall stone and risk increase with age $>35$ years (Fig 1a, Fig 2).

Triglycerides and high-density lipids were found to be statically significant with $\mathrm{p}<0.05$. Triglycerides in patients were higher than normal i.e. $\quad \begin{array}{lllll} & & ( \pm 0.7) & \mathrm{mmol} / \mathrm{l}>1.45 \quad( \pm 0.8) & \mathrm{mmol} / \mathrm{l}\end{array}$ respectively. Whereas High density lipids showed reciprocal relationship with cholelithiasis being lower in patients than healthy groups i.e. 0.95 $( \pm 0.2) \mathrm{mmol} / \mathrm{l}<1.05( \pm 0.2) \mathrm{mmol} / \mathrm{l}$ respectively. Total cholesterol and low-density lipids were higher in patients compared to the normal controls, [4.5 $( \pm 1.3) \mathrm{mmol} / \mathrm{l}>4.45( \pm 0.8) \mathrm{mmol} / \mathrm{l}]$ and $[2.65$ $( \pm 1) \mathrm{mmol} / \mathrm{l}>2.55( \pm 0.6) \mathrm{mmol} / \mathrm{l}]$ respectively but were not statically significant with $\mathrm{p}>0.05$ (Table 2, Fig 3).

\section{DISCUSSION AND CONCLUSIONS}

Cholesterol gallstones are the result of biliary super saturation caused by cholesterol hypersecretion into the gallbladder, gallbladder hypo motility, accelerated cholesterol nucleation and crystallization, and mucin gel accumulation. ${ }^{9}$ All most about half of patients with gallstones will have an abnormal lipid profile. The association between gallstones, abnormal lipids and later increase in risk of coronary artery disease or stroke has been shown in many studies but most of patients are not screened for metabolic disordors. ${ }^{5}$ Our study observed low serum HDL levels and high serum TG level in patients with cholelithiasis as compared to the control group and the difference was statistically significant. While for the total cholesterol and LDL the difference between patient and control group were not statistically significant. This result was in accordance to Channa NA et al, found that serum lipid elevation seemed to play a major contributing role in the pathogenesis of gallstones and showed high total cholesterol and TG and low level of HDL in patients with cholelithiasis. ${ }^{6}$ However a study by Harshi et al concluded with, abnormal serum lipid profiles doesn't seem to be an essential feature in patients with cholesterol gall stone. ${ }^{7}$ According to a research by Carel Thijs et al, high level of serum triglycerides and low level of HDL were associated with cholesterol gall stones and also noted that pigment stone had similar patterns of lipid profiles and generated idea for the involvement of common pathways in pathogenesis of gall stones. ${ }^{8}$ Another study by Torben Jorgensen also found same result as of our study that there were high level of TG and low level of HDL in patients with gall stone. ${ }^{10}$

The study undertaken concluded finding high level of TG and low level of HDL in patients with cholelithiasis compared to normal population. It also established a relation of dyslipidemia as a risk factor of gall stones and could be used as preventive measures. Also suggested for screening of all patients with gall stone for dyslipidemia and vice-versa.

\section{REFERENCES}


1. Njeze GE. Gallstones. Niger J Surg. 2013;19(2):49-55.

2. Batajoo H, Hazra NK. Analysis of serum lipid profile in cholelithiasis patients. $\mathbf{J}$ Nepal Health Res Counc. 2013;11(23):535

3. Moghaddam AA, Khorram A, Bonjar MM, Mohammadi M, Ansari H. The prevalence and risk Factors of gallstone among adults in south-east of iran. A Population-Based Study. Glob J Health Sci. 2016;8(4):6067.

4. Apstein MD, Carey MC. Pathogenesis of cholesterol gallstones: A parsimonious hypothesis. Eur J Clin Invest. 1996; $26: 343-52$

5. Malik AA, Wani ML, Tak SI, Irshad I, Hassan NU. Association of dyslipidemia with cholilithiasis and effect of cholecystectomy on the same. International Journal of Surgery. 2011;9(8):641-42.

6. Channa NA, Khand F, Ghanghro AB, Soomro AM. Quantitative analysis of serum lipid profile in gallstone patients and controls. Pak J Anal Environ Chem. 2010;11(1):59-65.

7. Weerakoon HTW, Ranasinghe S, Navaratne A, Sivakanesan R, Galketiya KB, Rosairo S. Serum lipid concentrations in patients with cholesterol and pigment gallstones. BMC Res Notes. 2014; 7:548.
8. Thijs C, Knipschild P, Brombacher P. Serum lipids and gallstones. A casecontrol study. Gastroenterology. 1990; 99:943-949.

9. Ibrahim M, Sarvepalli S, Stiff GM, Rizk M, Bhatt A, Walsh RM, Hayat U, Garber A, Vargo J, Burke CA. Gallstones: Watch and wait, or intervene? Cleveland Clinic Journal of Medicine. 2018;85(4):323-331.

10. Jorgensen T. Gall stones in a Danish population. Relation to weight, physical activity, smoking, coffee consumption, and diabetes mellitus. Gut. 1989; 30:528-534. 
Table 1. Gender Distribution

\begin{tabular}{|c|l|l|l|}
\hline \multicolumn{2}{|c|}{ Group A } & \multicolumn{2}{c|}{ Group B } \\
\hline \multicolumn{2}{|c|}{ Total $=50$} & \multicolumn{2}{c|}{ Total $=50$} \\
\hline Male $=17$ & Female $=33$ & Male $=24$ & Female $=26$ \\
\hline
\end{tabular}




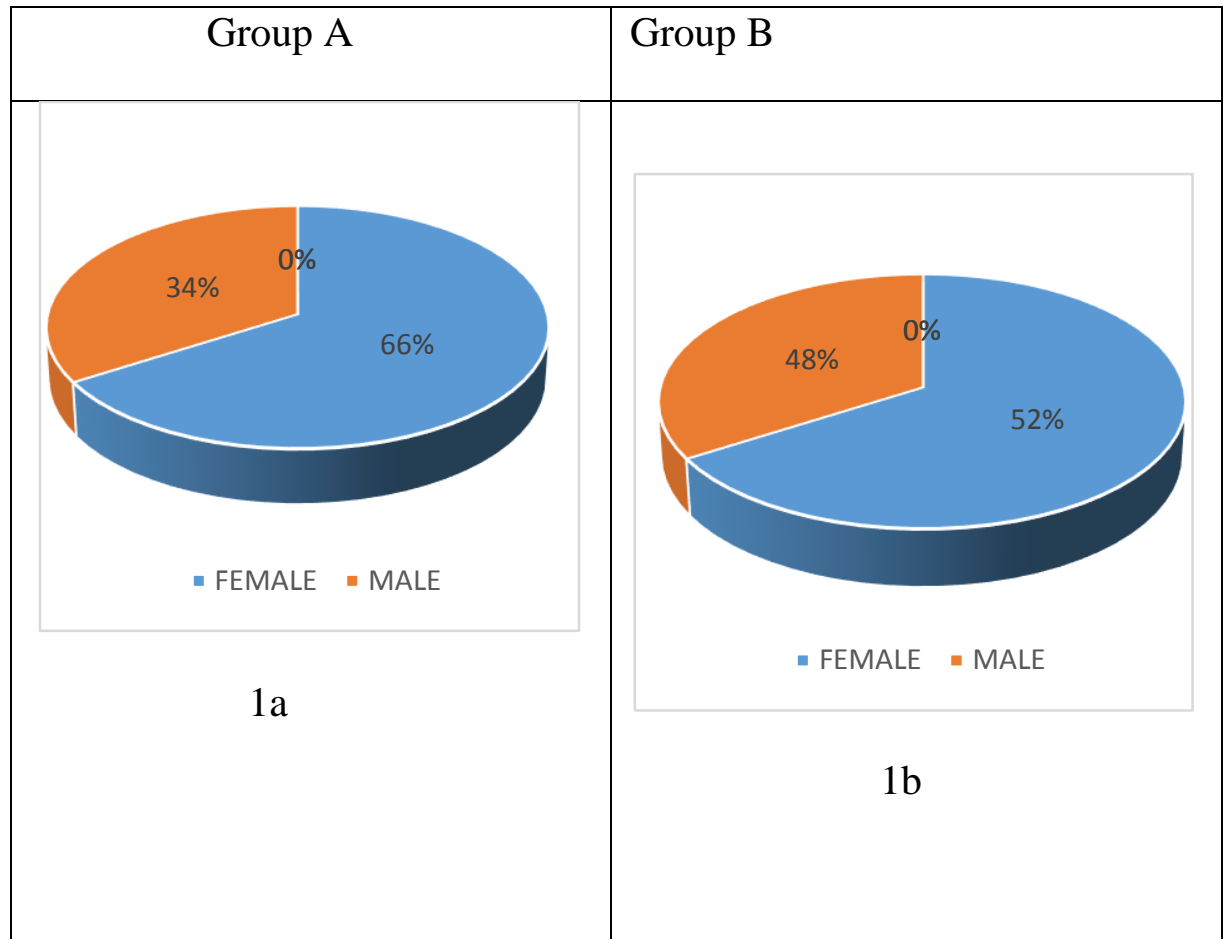

Figure 1. Percentage of male and female population in the groups 


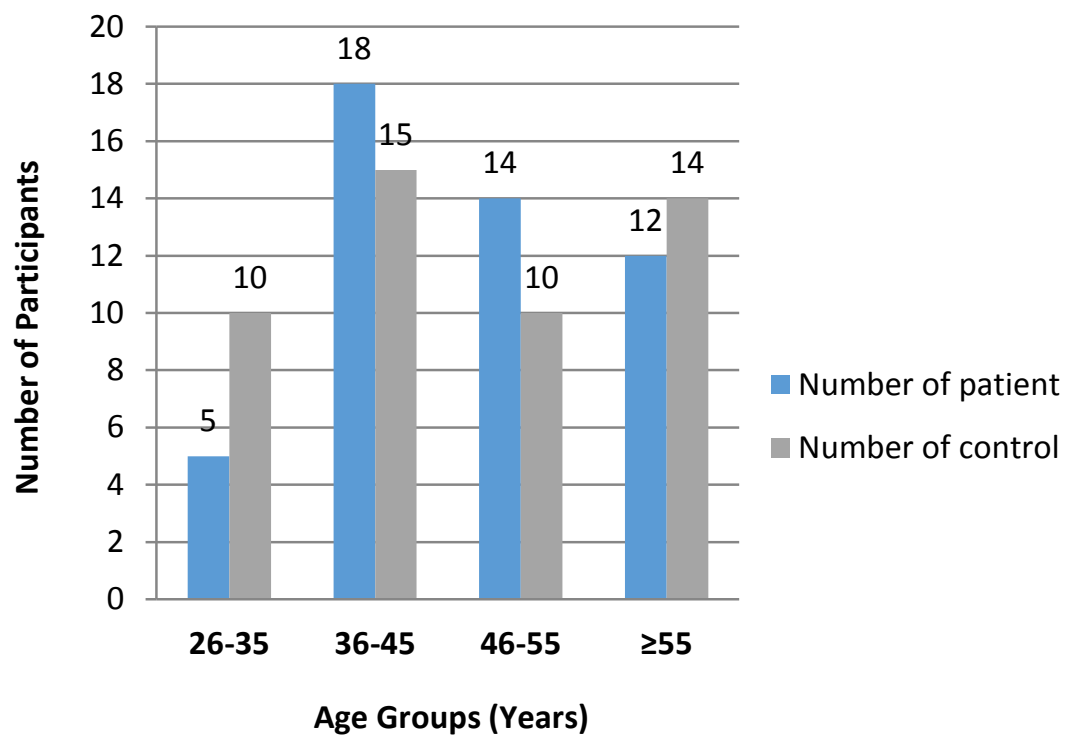

Figure 2. Age group classification of candidates 
Table 2. Serum lipid profiles in Group A and Group B

\begin{tabular}{|c|c|c|c|}
\hline Lipid Profile & Group A & Group B & $\mathrm{p}^{* *}$ \\
& $(\mathrm{Mean} \pm \mathrm{SD})^{*}$ & $(\mathrm{Mean} \pm \mathrm{SD})^{*}$ & \\
\hline Cholesterol (mmol/l) & $4.5 \pm 1.3$ & $4.45 \pm 0.8$ & 0.69 \\
\hline TG (mmol/l) & $1.9 \pm 0.7$ & $1.45 \pm 0.8$ & 0.005 \\
\hline HDL (mmol/l) & $0.95 \pm 0.2$ & $1.05 \pm 0.2$ & 0.001 \\
\hline LDL (mmol/l) & $2.65 \pm 1$ & $2.55 \pm 0.6$ & 0.72 \\
\hline
\end{tabular}

* Mean \pm standard deviation (SD); ** $<0.05=$ statically significant 
Figure 3. Bar diagram showing average of lipid profiles

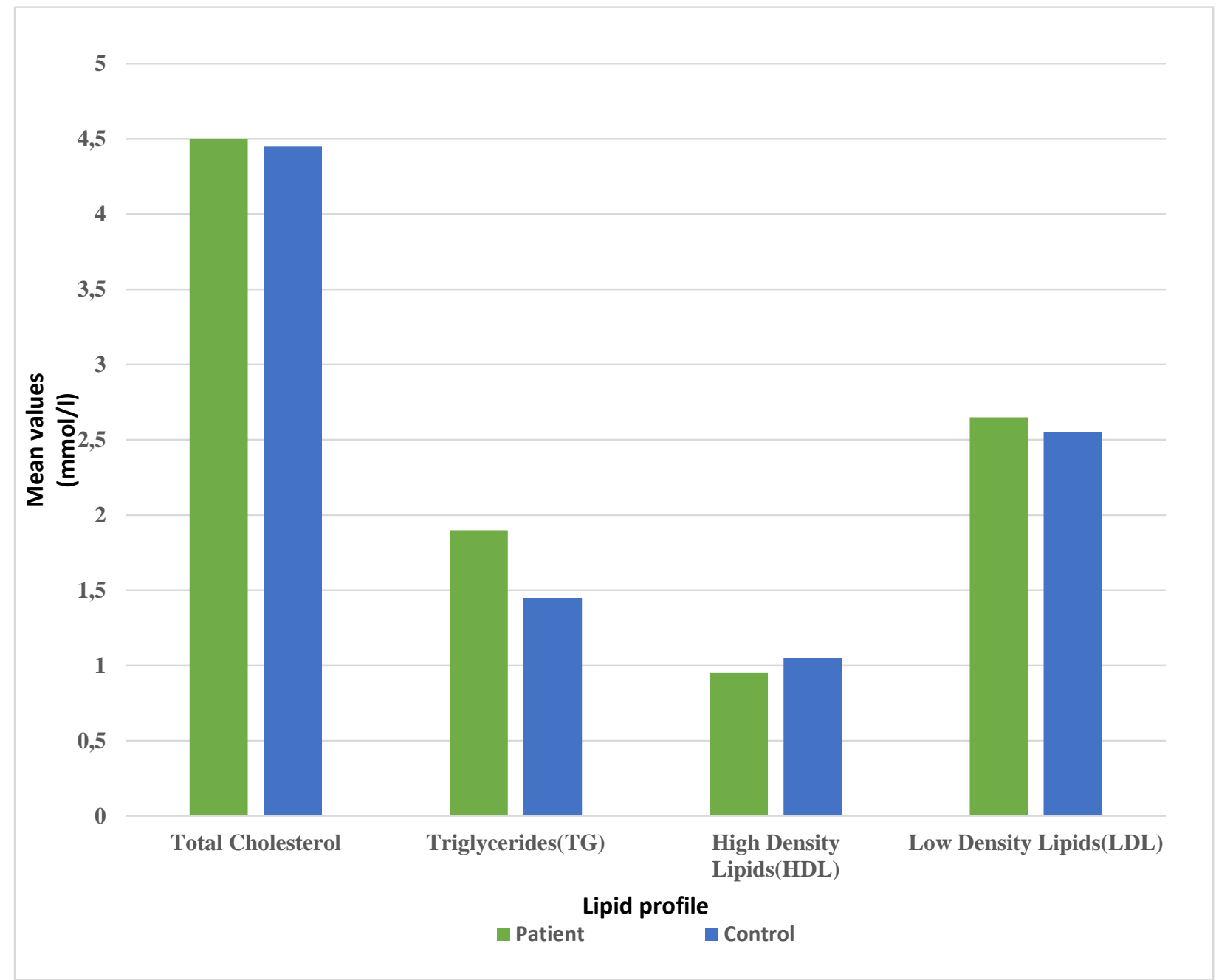

